\title{
Socio-Environmental surveys of Tinchuley and Takdah: Two emerging ecotourism hamlets of North Bengal, India
}

\author{
Sayan Bhattacharya ${ }^{1,2, *}$, Uday Chand Ghosh ${ }^{2}$ \\ ${ }^{1}$ Department of Environmental Studies, Rabindra Bharati University, Kolkata, India \\ ${ }^{2}$ Department of Chemistry, Presidency University, Kolkata, India \\ *E-mail address: sayan_evs@yahoo.co.in , sayan.evs@gmail.com
}

\begin{abstract}
Tinchuley (Latitude: $26.89748 \mathrm{~N}$, Longitude: $88.23268 \mathrm{E}$ ) is a remote hamlet located close to Darjeeling which can be reached through a drive of 32 kilometers. Takdah Cantonment (Latitude: 26.89745 N, Longitude: 88.23265 E) is a settlement located in Darjeeling district, West Bengal, India. It is one of the upcoming tourist centers of the Darjeeling hills, around $4 \mathrm{~km}$. from Tinchuley. The winding roads, tall pine and fir trees, intruding packs of cloud and warm and hospitable people makes it an ideal destination for people looking to escape from the hectic lifestyle of the city. The main objective of the present research work was to construct the social, environmental, cultural and economic framework of Tinchuley and Takdah Cantonment area and to highlight the proposals for sustainable management policies of those ecologically sensitive zones. The study was done in May, 2014 by visiting Tinchuley and Takdah and the information was gathered through field survey and direct contact with common people and authorized centers of the regions. Surveys on the agriculture, horticulture, livestock, water management, education, culture, health, waste management, transport and biodiversity were done in these areas. Tinchuley and Takdah have become the prominent tourist spots of West Bengal for pleasure trips, biological and geographical excursions and medical research works. In spite of getting so much attention in the recent time, the areas are not adequately developed. There is an urgent need for implementing sustainable management systems in the areas for the betterment of the socio-environmental structures. Some of the possible management strategies have been suggested for maintaining the social, environmental, economic and ecological balance of the regions.
\end{abstract}

Keywords: Tinchuley; West Bengal; ecotourism, India

\section{INTRODUCTION}

The word Tinchuley stands for three chullas (chulla means oven), and this is represented by three prominent hill tops that resembles the three "chullas" or ovens. It is an upcoming tourist destination of the region [1]. Tinchuley (Latitude: 26.89748 N, Longitude: $88.23268 \mathrm{E}$ ) is a remote hamlet located close to Darjeeling which can be reached through a drive of 32 kilometers. It is at a distance of 80 kilometers from Siliguri, 35 kilometers from Kalimpong and 88 kilometers from Gangtok [2]. The winding roads, tall pine and fir trees, intruding packs of cloud and warm and hospitable people makes it an ideal destination for 
people looking to escape from the hectic lifestyle of the city. The inhabitants of this quiet settlement took an initiative for establishing their locality as a model organic village. Even a few years back Tinchuley was a remote hamlet. The inhabitants of this quite settlement took an initiative for establishing their locality as a model village. With the help of organizations such as the WWF, the village soon developed eco-tourism resorts. The villagers also showed keen interest in modern farming and with the help of WWF they developed floriculture, vermiculture, organic projects [3]. The villagers also showed keen interest in modern farming and with the help of WWF they developed floriculture, vermicomposting, organic projects.

Takdah Cantonment (Latitude: 26.89745 N, Longitude: 88.23265 E) is a settlement located in Darjeeling district, West Bengal, India. It is one of the upcoming tourist centers of the Darjeeling hills, around $4 \mathrm{~km}$. from Tinchuley. It has an altitude of 1580 meter, the annual average temperature is around $26{ }^{\circ} \mathrm{C}$ and annual average rainfall is $2488 \mathrm{~mm}$. approximately (the meteorological information was collected from Takdah research station, Govt. of West Bengal). Takdah Cantonment, as the name signifies, was a British cantonment before the independence of India. It was the destination for many British officers of high rank from all over India [4]. After independence, like many other towns and villages, Takdah was abandoned by the new order. It was only recently that people really started to settle down in the area. Though the British are long gone, we can still find the beautiful structures erected during the British era. Takdah is the headquarters of the Rangli Rangliot development block. The main junction of Takdah is called Dara Dokan. A weekly market, held every Thursday, is a sight worth watching as people from all the nearby villages come to shop their weekly needs. The town of Darjeeling is $30 \mathrm{~km}$ away and Takdah is well connected with Darjeeling with buses and jeeps plying constantly.

The main objective of the present research work was to construct the social, environmental, cultural and economic framework of Tinchuley and Takdah area and to highlight the proposals for sustainable management policies of those ecologically sensitive zones.

\section{METHODS OF THE SURVEY WORK}

The study was done in May, 2014 by visiting Tinchuley and Takdah and the primary data were gathered through field survey and direct contact with common people and authorized centers of the region. Information on agricultural activities is collected from the local villagers. Report on the silviculture unit (hills) of Takdah research station was prepared based on the information displayed there and the names of the chemicals used in the cultivation were collected from the chemical stocks kept in the unit. Information regarding the transport system was collected from the local transport office and syndicate. Religious and social festival information was collected from the local people and from the Buddhist monastery. Health and education information was collected from the local primary and high schools and the local sub health centre. Information on environmental activities like using sustainable agricultural practices and waste management policies is collected through surveys in the villages and from the local hotels situated in Tinchuley and Takdah. Pictorial documentation was done in every phase of study [5].

\section{AGRICULTURE AND LIVESTOCK}

In the hill areas of Tinchuley and Takdah, terrace cultivation or step cultivation is practiced (Figure 1). It is method of growing crops on sides of hills or mountains by planting 
on graduated terraces built into the slope. Though labour-intensive, the method has been employed effectively to maximize arable land area in variable terrains and to reduce soil erosion and water loss.

In Tinchuley, the common cultivable edible plants are rice, wheat, maize, garlic, ginger, cauliflower, cabbage, beans, radish, brinjal, round chilli, pumpkin etc. The people of Tinchuley usually practiced organic farming, cowdung is used as common manure. Interestingly, they cultivated maize in the same land after potato cultivation, as after collecting the potatos, the soil is very well mixed up and there is no need for further digging. Large Cardamom (Amomum subulatum) was cultivated in Tinchuley, however, in recent times, the production has been severely affected by the shortage of water and changing climate (according to local reports). Our previous paper also reported the decrease in production of large cardamom in Rishop, another hill station of North Bengal [5]. Most of the houses in Tinchuley have cultivable lands adjacent to the houses and farming is done there. Agricultural production is one of the main economic sources of the people in Tinchuley and Takdah. They used to sell the foods in the markets after production. Honey production is also an important source of earning. The inhabitants used to make artificial wooden structures in which bees take shelter and store honey. They periodically collect the honey and supply it to market.

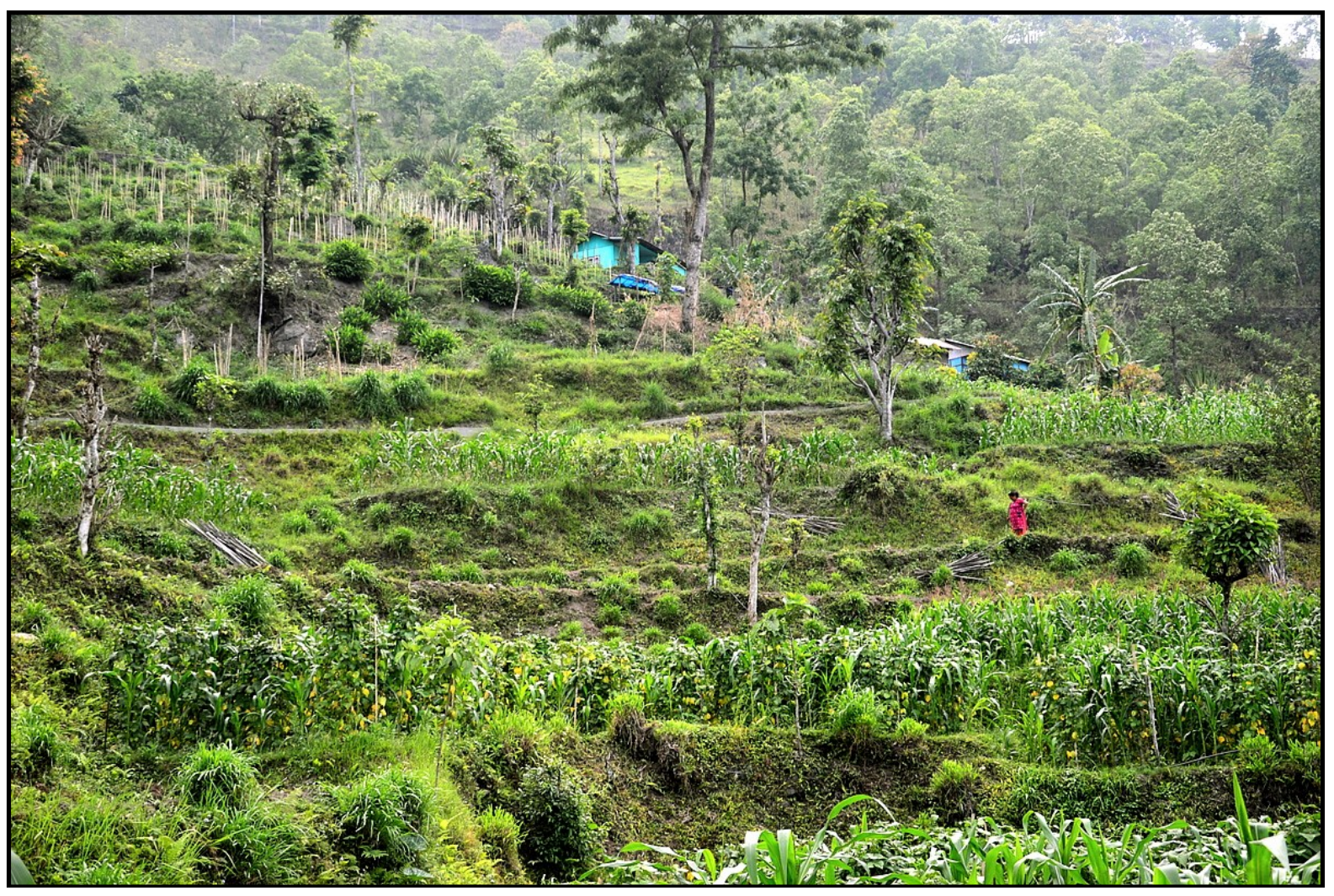

Figure 1. Step Cultivation in Tinchuley.

The common livestock at Tinchuley and Takdah are cow, goat and pig. Local poultry farms are found in many houses. Meat and milk are the main livestock products which are one of the important economic sources. Several locally made milk products are sold in the 
local markets and are supplied to Siliguri, Darjeeling and Kalimpong. In Soreng, a village near Tinchuley, there is a veterinary sub centre, where treatment of the cattle is done.

\section{SILVICULTURE AND HORTICULTURE PRACTICES}

\section{A. Takdah Research Station:}

Takdah Research Station, Silviculture (Hills) was established by the Government of West Bengal for the practice of controlling the establishment, growth, composition, health, and quality of forest plants of economic importance (Figure 2). One of the main objectives of this kind of unit is to improve the growing stock of forest in hilly areas of North Bengal [6]. Various steps are taken here for the tree improvement, which include the selection, nursery work and plantations. Clonal propagation is an important part of Tree Improvement Programme in the silviculture unit. It is done by grafting and cutting in the specially designed mist chamber (permanent and temporary tunnels) and glass houses in all the nurseries of silviculture division [6]. In the mist chambers, the clonal propagation work is being carried out throughout the year. There are three permanent mist chambers at Takdah research station. Irrigation water is collected from the hills and long pipelines distribute irrigation water in the fields. In the glass houses, sprinkler irrigation is done.

All the seeds collected in the research station are cleaned, graded and tested for its germination time, germination period, germination percentage and then supplied to the divisions under certification. Seeds of longer viability are stored in poly bags and sealed containers in seed store houses. In the recent years, efforts are being made to improve the nursery techniques in order to increase the efficiency so as to get improved quality of seedlings in short times. The following methods are being introduced as modern nursery practice:

1. Making of compost and proper soil mixture.

2. Use of root trainer.

3. Installation of self root pruning bed.

4. Irrigation by overhead spraying system.

5. Agronet as a shade.

With these newly introduced techniques, the nursery time of most of the species particularly in the hill areas have reduced to almost half of its normal time that used to take place earlier [6].

The clone (ramit) which are prepared in the nurseries are utilized in the clonal plantation in all the research stations situated in North Bengal. The clonal plantations have been done in the following forms:

1. Clonal seed orchard.

2. Clonal bank orchard.

3. Clonal multiplication garden and hedge in nursery [6].

Several synthetic chemicals are also used for the cultivation in the silviculture unit like: Roodex (Root hormone), Ripcord (Emulsifiable concentrate containing Cypermethrin for insect control), Bavistin (systemic broad spectrum fungicide with protectant and eradicant activities), Gibberellic acid $0.001 \%$ (Plant growth regulator), Biozyme (liquid biofertilizer 
which can stimulate soil microbes and can increase the availability of soil nutrients and they also play a significant role in defending against soil-based diseases), Tracel (scientifically formulated blends of micronutrients in soluble, crystalline form) etc. Figure 3 shows Quercus lineata cultivation in a green house at Takdha Research Station.

\section{A list of medicinal plants cultured in the research station is given below}

\begin{tabular}{|c|c|c|c|c|}
\hline $\begin{array}{c}\text { Botanical } \\
\text { Name }\end{array}$ & Local Name & Family & Part used & Medicinal use \\
\hline $\begin{array}{c}\text { Dichroa febrifuga } \\
\text { Lour }\end{array}$ & Basak & Saxifragaceae & Leaves & Malaria \\
\hline $\begin{array}{c}\text { Artemisia vulgaris } \\
\text { Linn. }\end{array}$ & Titey Pati & Compositae & Leaves & Nose bleeding \\
\hline $\begin{array}{c}\text { Girardinia } \\
\text { heterophylla Decn. }\end{array}$ & Bhangrey sishnu & Urticaceae & Young shoot & High blood pressure \\
\hline $\begin{array}{l}\text { Rumex nepalensis } \\
\text { Spreng. }\end{array}$ & Halhaley & Polygoniaceae & Root & Diarrhoea \\
\hline $\begin{array}{c}\text { Eupatorium } \\
\text { cannabinum Linn. }\end{array}$ & Banmara & Compositae & Leaves/Shoots & Antidote \\
\hline $\begin{array}{c}\text { Phytolacca acinosa } \\
\text { Roxb. }\end{array}$ & Jaringo & Phytolaccaceae & Roots & Joint pains \\
\hline $\begin{array}{c}\text { Swertia chirayita } \\
\text { (Rox. Ex. Flem.) } \\
\text { Karst. } \\
\end{array}$ & Chirauto & Gentianaceae & Leaves and roots & Fever \\
\hline $\begin{array}{c}\text { Remusatia pumlla } \\
\text { (D.Don) H.LI \& } \\
\text { A.Hary }\end{array}$ & Dhungey & Aroideae & Roots & Mumps \\
\hline $\begin{array}{l}\text { Costus speciosa } \\
\text { Koem. }\end{array}$ & Bet louri & Castaceae & Leaves/Roots & Liver disorder \\
\hline $\begin{array}{c}\text { Clematis } \\
\text { buchananiana Dc. }\end{array}$ & Pinase Lahara & Menispermaceae & Whole plant & Sinus \\
\hline $\begin{array}{c}\text { Pouzolzia hirta } \\
\text { Hassk. }\end{array}$ & Chipley & Euphorbiaceae & Whole plant & Bone fracture \\
\hline $\begin{array}{c}\text { Citrullus } \\
\text { colocynthes Schred }\end{array}$ & Indreni & Cucurbitaceae & Fruits/Roots & Diarrhoea \\
\hline $\begin{array}{l}\text { Potentila fulgens } \\
\text { Wall. }\end{array}$ & Mulijhar & Rutaceae & Rhizome & $\begin{array}{c}\text { Piles, Blood } \\
\text { dysentery }\end{array}$ \\
\hline $\begin{array}{c}\text { Nephrolepsis } \\
\text { cordifolia Persl. }\end{array}$ & Pani Amala & Lycopodiaceae & Roots & Jaundice \\
\hline $\begin{array}{c}\text { Astilbe rivularis } \\
\text { Ham. }\end{array}$ & Buro okhathi & Saxifragaceae & Roots & Stomach ailments \\
\hline Juglans regia Linn. & Okhar & Juglandaceae & Bark leaves & Cancer \\
\hline $\begin{array}{l}\text { Quercus lamellosa } \\
\text { Sm. }\end{array}$ & Buk & Fagaceae & Seed & Chest pain \\
\hline $\begin{array}{c}\text { Taxus wallichinia } \\
\text { Zucc. }\end{array}$ & Dhyangre sallah & Taxaceae & Tenol & Cancer \\
\hline $\begin{array}{l}\text { Kaempferia rotunda } \\
\text { Linn. }\end{array}$ & Bhui champa & Zingiberaceae & Rhizome & Leucaderma \\
\hline $\begin{array}{c}\text { Acorus calamus } \\
\text { Linn. }\end{array}$ & Bojo & Araceae & Root/Rhizome & $\begin{array}{l}\text { Antipyretic, } \\
\text { Epilepsy }\end{array}$ \\
\hline $\begin{array}{l}\text { Curcuma longa } \\
\text { Linn. }\end{array}$ & Hardi & Scitaminceae & Rhizome & Appetizer \\
\hline
\end{tabular}




\begin{tabular}{|c|c|c|c|c|}
\hline $\begin{array}{c}\text { Curcuma amada } \\
\text { Roxb. }\end{array}$ & Phacheng & $\begin{array}{l}\text { Scitaminceae/ } \\
\text { Zingiberaceae }\end{array}$ & Root/Rhizome & $\begin{array}{c}\text { Itching and skin } \\
\text { diseases }\end{array}$ \\
\hline $\begin{array}{c}\text { Bergenia ciliata } \\
\text { Sternb. }\end{array}$ & Pakhan bed & Saxifragaceae & Whole plant & Cough and cold \\
\hline $\begin{array}{c}\text { Campylandra } \\
\text { aurantiaca Walt. }\end{array}$ & Nakima & Liliaceae & Roots & Jaundice \\
\hline $\begin{array}{c}\text { Prunus cerosoides } \\
\text { D.Don }\end{array}$ & Painyu & Rosaceae & Fruits & Stone and abortion \\
\hline $\begin{array}{c}\text { Zanthoxylum } \\
\text { oxyphyllum Edgew. }\end{array}$ & Lahare timbur & Rutaceae & Fruits/seeds & Appetizer \\
\hline $\begin{array}{l}\text { Fraxinus paxiana } \\
\text { Ling. }\end{array}$ & Lakure & Oleaceae & Leaves & Gout \\
\hline $\begin{array}{c}\text { Brassaiopsis } \\
\text { speciosa } \text { Decne \& } \\
\text { Plunch }\end{array}$ & Chinde & Araliaceae & Shoots & Diabetes \\
\hline $\begin{array}{c}\text { Salix babylonica } \\
\text { Linn. }\end{array}$ & Bains & Salicineae & Leaves/Bark & Remittent \\
\hline $\begin{array}{c}\text { Buddleja asiatica } \\
\text { Lour. }\end{array}$ & Rhimsen pati & Loganiaceae & Leaves/Flowers & Skin diseases \\
\hline $\begin{array}{c}\text { Cinnamomum } \\
\text { obtusifolium Nees. }\end{array}$ & Sinkauli & Lauraceae & Leaves/Bark & Piles, heart diseases \\
\hline $\begin{array}{l}\text { Rhododendron } \\
\text { arboreum } \mathrm{Sm} .\end{array}$ & Lali gurash & Ericaceae & Flower & Dysentery \\
\hline $\begin{array}{c}\text { Valeriana wallichii } \\
\text { Dc. }\end{array}$ & Sugandra Bal & Valerianaceae & Rhizome & $\begin{array}{l}\text { Sedative } \\
\text { tranquilizer }\end{array}$ \\
\hline $\begin{array}{c}\text { Phlogacanthus } \\
\text { thrysiformis } \\
\text { Mabberly } \\
\end{array}$ & Chuha & Acanthaceae & Inflorescence & Diabetes \\
\hline $\begin{array}{c}\text { Parochaetus } \\
\text { communis Ham. }\end{array}$ & Muli jhar & Leguminosae & Roots & Gastritis \\
\hline $\begin{array}{c}\text { Litsea citrata } \\
\text { Blume }\end{array}$ & Siltimur & Rutaceae & Fruits & Stimulant, flatulent \\
\hline $\begin{array}{l}\text { Mentha arvensis } \\
\text { Linn. }\end{array}$ & Kalo padina & Labiatae & Shoots & Stimulant, flatulent \\
\hline $\begin{array}{l}\text { Digitalis pupurea } \\
\text { Linn. }\end{array}$ & Jandi phul & Scrophulariaceae & Leaves/flower & $\begin{array}{c}\text { Bodyach/Cardiac } \\
\text { problems }\end{array}$ \\
\hline $\begin{array}{c}\text { Tupistra nutans } \\
\text { Wall. }\end{array}$ & Tite/Thulo nakima & Hemodoraceae & Inflorescence & $\begin{array}{c}\text { Hyper tension, } \\
\text { diabetes }\end{array}$ \\
\hline $\begin{array}{l}\text { Selinum tenuifolium } \\
\text { Wall. }\end{array}$ & Bhut kesh & Umbelliferae & Whole Plant & For cough \\
\hline $\begin{array}{l}\text { Withania somnifera } \\
\text { Dunal }\end{array}$ & Ashwa gandha & Solanaceae & Whole Plant & Tonic \\
\hline $\begin{array}{c}\text { Tinospora } \\
\text { cordifolia }(\text { Wild) } \\
\text { Miers }\end{array}$ & Gurjo Lahara & Menispermaceae & Stem & Stimulant, Tonic \\
\hline
\end{tabular}




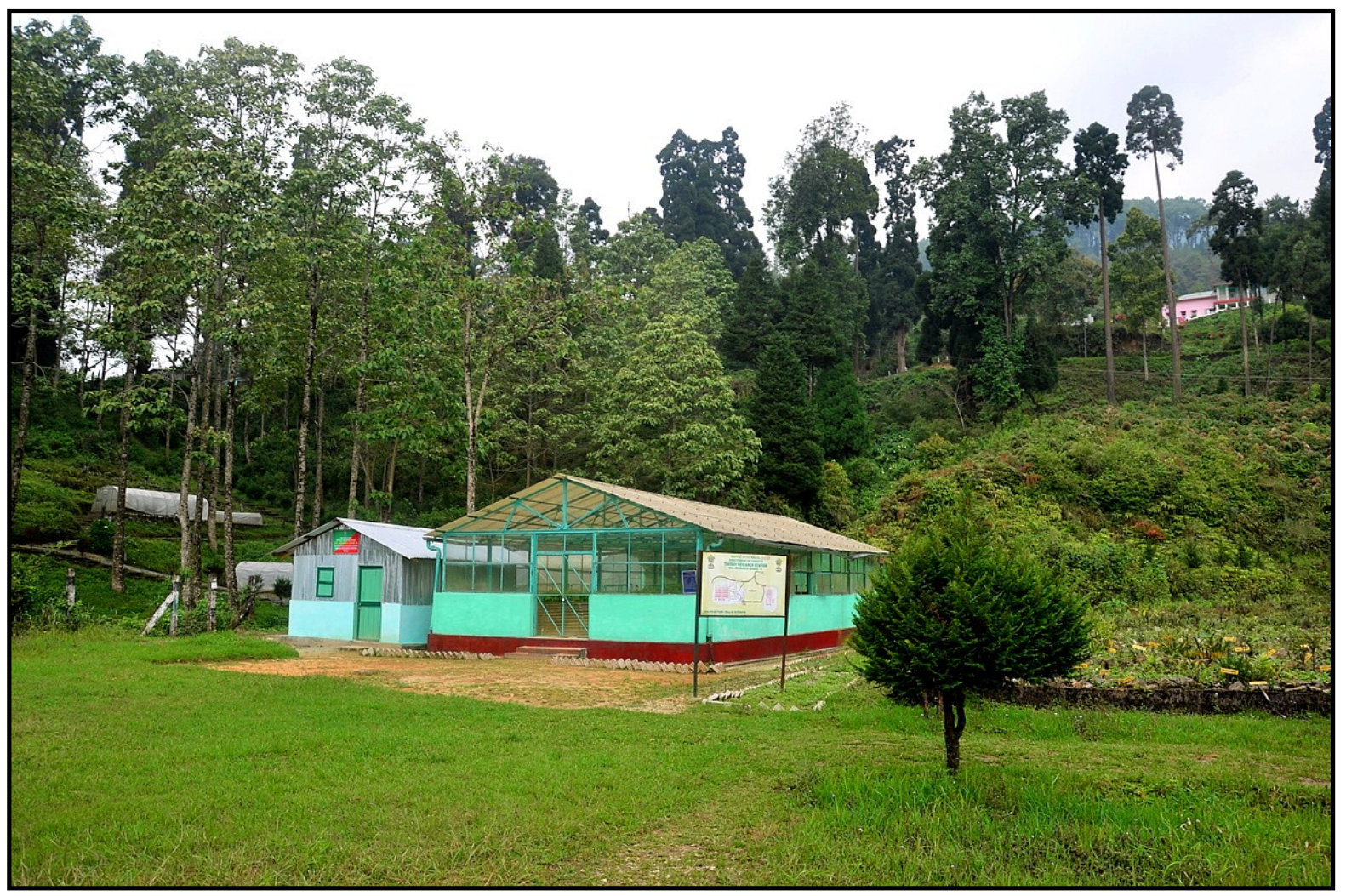

Figure 2. The green houses of Takdah Research Station.

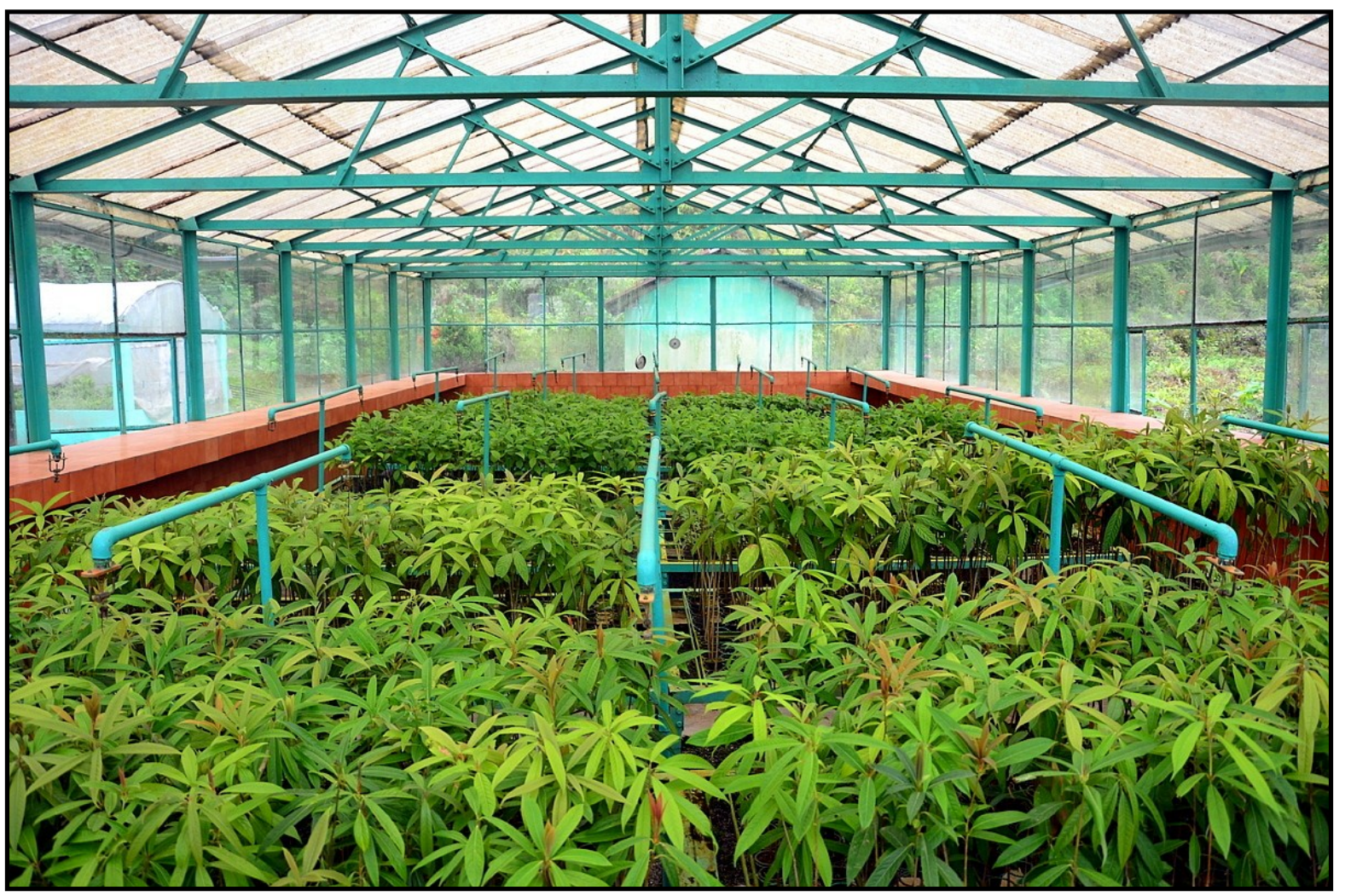

Figure 3. Quercus lineata cultivation in a green house at Takdah Research Station. 


\section{B. Orange (The orchard gateway):}

Orange (The orchard gateway) is an orange garden of private ownership near Tinchuley (Figure 4).

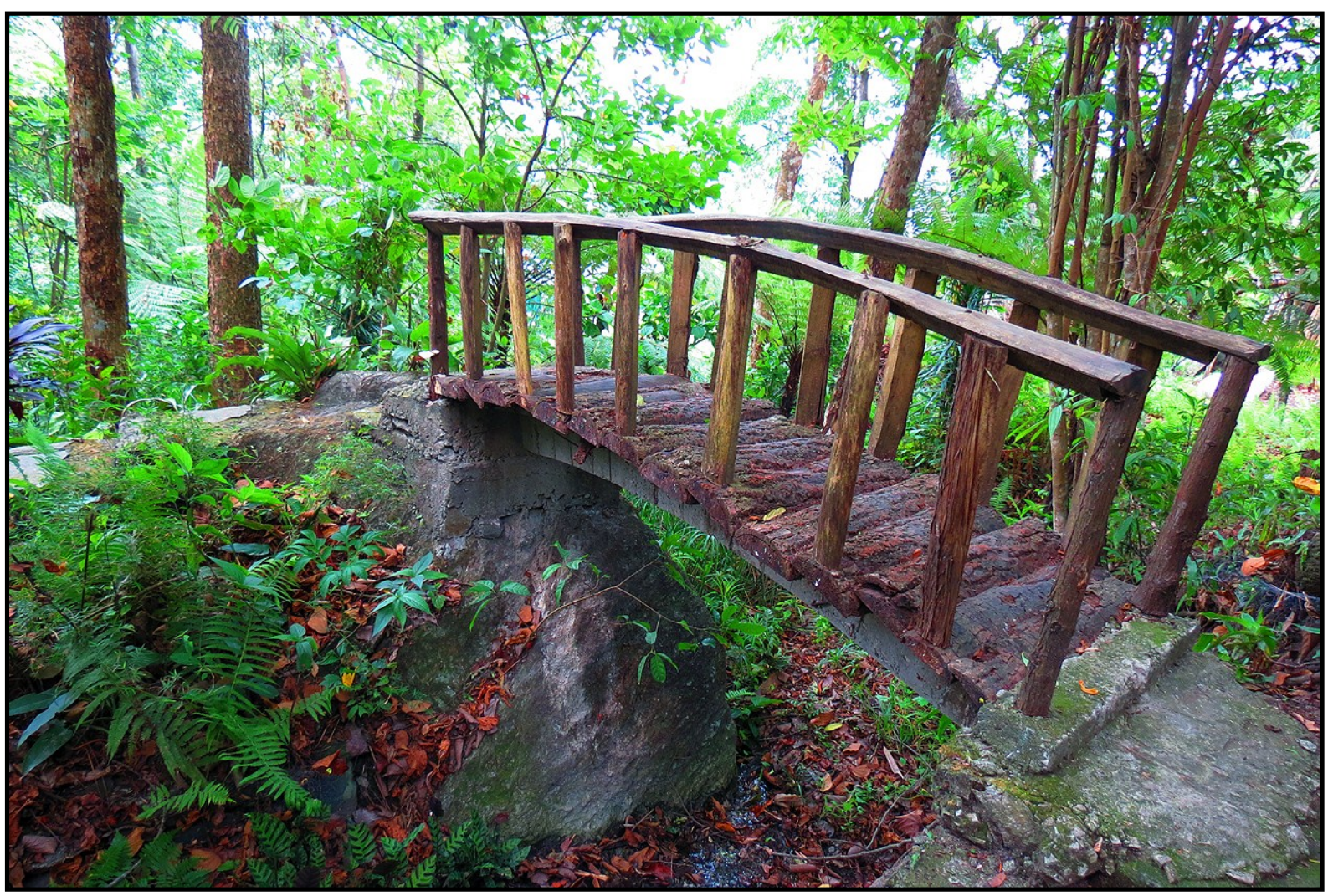

Figure 4. The orange orchard in Tinchuley.

The location is at Santala Bagan, Baramangwa Busty, Via Teesta Bazar. The garden was established by Nirmal Das (Gurung) in 1930. Now his grandson Satyadeep Gurung has taken the responsibility of managing the garden. Several plant species of medical and economic importance are cultivated there. Some of the important cultivated plants are:

1. Common Fig (Ficus sp.), which is used as fruit and ornamental plant.

2. Tree fern, which is very much local and nowadays facing severe threats due to deforestation.

3. India Bay Leaf (Cinnamomum tamala), which is used as flavouring agent and insecticides.

4. Anthurium flower (Anthurium sp.), used for decoration.

5. Rudraksha (Elaeocarpus ganitrus), whose seed is traditionally used for prayer beads in Hinduism.

6. Bet Louri (Costus speciosa), which is a medicinal plant and is effective in liver disorder.

7. Strawberry Tree (Arbutus unedo), a tree with edible fruits.

8. Varieties of round chilies.

9. Betel leaf (Piper sp.), whose leaf are edible and mild stimulant.

10. Lychee (Litchi chinensis), plant with edible fruits.

11. Mousambi (Citrus limetta), plant with edible fruits. 
12. Avocado (Persea americana), plant with edible fruits (large berry).

13. Large cardamom (Amomum subulatum), a spice-producing plant.

14. Cinnamon (Cinnamonum sp.), a spice-producing plant.

15. Tree plants of Chinese varieties.

16. Indra Kamal flower (Gardenia jasminoides), flowers for decoration.

17. Bakain tree (Melia azedarach), the sedds of which are used as insect repellent.

18. Mandarin orange (Citrus reticulate), plant with edible fruits.

The agricultural techniques applied in the farm are discussed as follows:

1. Irrigation water is collected from the hills and long pipelines distribute irrigation water in the fields. In the middle of the garden, there is a storage tank where the water is stored. Sparkling irrigation was also done in the field.

2. Organic farming is practiced in the farm and soil is enriched by the process of organic mulching. Mulches are materials placed over the soil surface to maintain moisture and improve soil conditions. Mulching is one of the most beneficial things a home owner can do for the health of a tree. Mulch can reduce water loss from the soil, minimize weed competition, and improve soil structure [7]. Cowdung is used in the orange orchard as manure and a layer of cow dung is applied on the surface soil, over which a layer of dead leaves are placed. The process helps to form the humus in soil, can increase the aeration and drainage capacity of the soil. It also helps in root growth and development, can reduce the soil moisture through evaporation, can protect roots from extreme summer and winter temperatures, can inhibit certain plant diseases and can control weed germination and growth [7]. The decomposition process in mulching completes in about 30 days.

3. Multiple crop farming (practice of growing two or more crops in the same space during a single growing season, a form of polyculture) is done for disease control.

4. Legume plants are cultivated at regular interval for increasing the soil fertility and nitrogen fixation.

5. Permaculture farming is practiced in the farm (Permaculture is a term which is a combination of the words "permanent" and "agriculture". Permaculture is a branch of ecological design, ecological engineering, environmental design, construction and Integrated Water Resources Management that develops sustainable architecture, regenerative and selfmaintained habitat and agricultural systems modeled from natural ecosystems) [8].

6. Several species of Chinese tea are cultivated in the garden for reducing the incidence of soil erosion. The tea plantation is done at the edge of the garden.

7. Several fungal and viral diseases of plants are affecting the species of the garden. Gummosis (Gummosis is the formation of patches of a gummy substance on the surface of certain plants, particularly fruit trees) is one of the common plant diseases of the garden. Citrus Tristeza virus (CTV) is a viral species of the Closterovirus genus [9] that causes the most economically damaging disease to the citrus plants cultivated here. Micropropagation of Darjeeling orange (Darjeeling mandarin) is done by shoot-tip grafting technique for mitigating the plant disease caused by Tristeza virus (Figure 5). For the treatment of the plant diseases, several plant products are applied as fungicide and virucide. For example, Equisetum sp., a variety of grass is cultivated in the orchard. The grass is boiled and the extract is mixed with water, which has anti fungal activity. The extract is applied on the citrus 
plants for disease control. The Bakain tree seeds are crushed and mixed with water, which is an excellent insect repellent. This extract is also used for disease control in the farm.

8. Recently, the owners of the farm heave started to practice the biodynamic farming. Biodynamic agriculture is a method of organic farming originally developed by Rudolf Steiner that employs what proponents describe as "a holistic understanding of agricultural processes". One of the first sustainable agriculture movements, it treats soil fertility, plant growth, and livestock care as ecologically interrelated tasks, emphasizing spiritual and mystical perspectives [10]. Proponents of biodynamic agriculture, including Steiner, have characterized it as "spiritual science" as part of the larger anthroposophy movement. A distinguishing feature of biodynamic farming is the use of nine biodynamic preparations described by Steiner for the purpose of enhancing soil quality and stimulating plant life. They consist of mineral, plant, or animal manure extracts, usually fermented and applied in small proportions to compost, manures, the soil, or directly onto plants, after dilution and stirring procedures called dynamizations. The original biodynamic (BD) preparations are numbered 500-508. The BD 500 preparation (horn-manure) is made from cow manure (fermented in a cow horn that is buried in the soil for six months through autumn and winter) and is used as a soil spray to stimulate root growth and humus formation. The BD 501 preparation (hornsilica) is made from powdered quartz (packed inside a cow horn and buried in the soil for six months through spring and summer) and applied as a foliar spray to stimulate and regulate growth. The next six preparations, BD 502-507, are used in making compost. Finally, there is BD preparation 508 which is prepared from the silica-rich horsetail plant (Equisetum arvense) and used as a foliar spray to suppress fungal diseases in plants. However the biodynamic concept of agriculture is somewhat debatable.

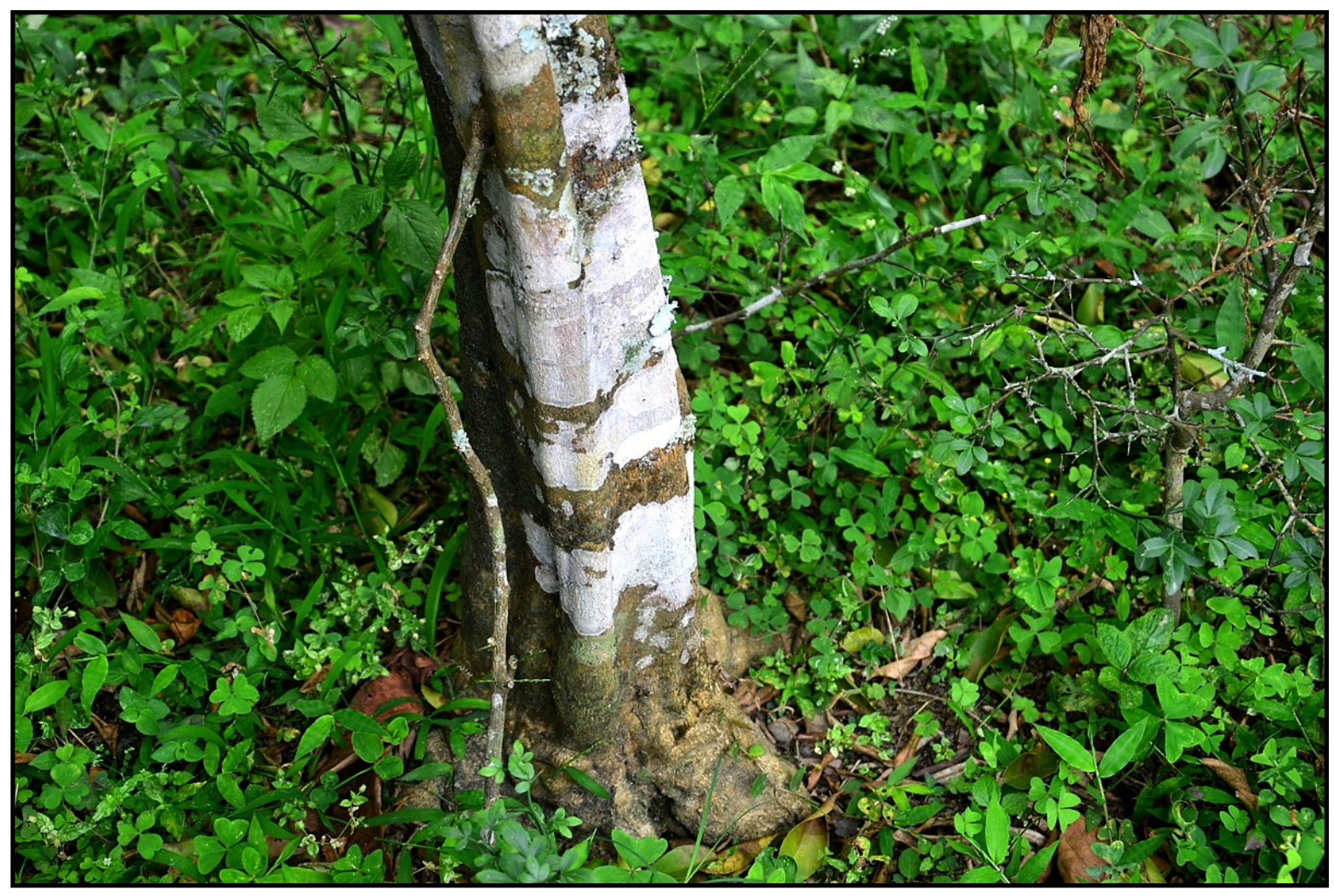

Figure 5. Shoot-tip grafting technique for mitigating plant disease at Tinchuley orange garden. 


\section{WATER MANAGEMENT}

The main water source of Tinchuley and Takdah is the water coming from the hills through channels like "jhoras". Artificial cisterns are made to collect and store the hill water. The cement made cisterns are situated at the hills, around 5-6 km. away from Tinchuley. Extensive network of pipeline distributes the water from the cisterns to the houses. Each house has its own water collecting and storing unit from which they get the supply. Additionally, people used to bring water from the water sources in the hills. Near Tinchuley, the Teesta Valley region faces periodical water crisis, especially in the dry seasons. Interestingly, before any social occasion festival, the people start to collect and store water at least two months before the event. Even the relatives and neighbours send buckets of water to the house as gift during the event. On the way from Tinchuley to Darjeeling, there are several vehicles which collect water from the hill "jhoras" and supply to the water stressed zones. Water is treated as a commodity in some water stressed areas there, and a good source of income. In some houses, roof top rainwater harvesting structures was observed. The roofs have aluminium gutters (long, hollow device that is attached to the edges of the roof to catch rain and carry it away from a building) at the corner for collecting rainwater. The roofs have inclined slope, so that water flows easily in the gutter. The rainwater falling on the roof top can be collected through these gutter channels. Pipes are connected with the gutters through which water can be collected in the cisterns and containers [5]. The collected rainwater is used for bathing, washing and irrigation purpose. For drinking purpose, the people depend on the hill water sources.

\section{EDUCATION, CULTURE AND HEALTH}

The major ethnic groups of Darjeeling district are Lepcha, Bhutia and the Nepalese. Nepalese is a conglomerate of Mongoloid tribal like Sherpa, Limbu, Tamang, Yolmo, Kagatay, etc. and the Aryan non-tribal like Chhetri, Bahun, Sanyasi, Kami, Damai, etc [11]. Intermediates between these two groups are the Newas, showing partial characteristics of both the groups. Each of these tribal groups has its own distinct culture, language and traditions. However, Nepali language is the medium of communication between the tribes. These tribes also have rich ethnomedicinal traditions. The tough terrain and vast natural barriers force the people of this region to depend on herbal medicine. However, the use of traditional medicine is prevalent even among the urban people of this region.

Number of good educational institution are set up in Takdah nearby bazar there is one co-residential English medium school Tiny Angels' School which follows ICSE syllabus provides good source of knowledge and education to people residing out there. Moreover Foreign Teachers do visit this school and sponsors the financially weak but good students. The main school at Tinchuley and Takdah are Takdah Griffith High School (established in 1936). In Tinchuley, there are four schools, three of which are private and one is government. In Takdah, in addition to the Griffith School, there are three Government and six private schools.

At Takdah, there is an old health centre for general treatment. Three doctors are there, with several nurses and staffs. One labour room is there, but no operation is done in that centre. People of Tinchuley and Takdah used to go to Kalimpong and Darjeeling for major treatments and operations. 
The main festivals of Tinchuley and Takdah are Durga Puja, Dasara and Losar. Losar is the Buddhist festival ("Losar" in Tibetan language means New Year), which is celebrated for 15 days, however, the main celebration occurs in the first three days.

\section{WASTE MANAGEMENT}

In Tinchuley and Takdah, the people used to burn the waste materials in a specific empty place periodically. The hotels and resorts have their own burning places where they used to burn all the solid wastes. The unburned materials are buried in the ground. However, burial of the wastes, specially the hazardous ones, and burial of the wastes can affect the sensitive ecosystems of those areas, and can affect the inhabitants as well.

\section{TRANSPORT AND CONNECTIVITY}

Takdah is well connected with other adjoining areas of North Bengal. In public transports, there are one small private bus available in the morning which connect Tinchuley with Darjeeling. Additionally, there are cars which go to Siliguri from Takdah, carrying passengers on sharing basis. There are also sufficient numbers of private cars which can be hired for going different parts of North Bengal. In Tinchuley, there are around 15-20 private cars which can also be hired for sightseeing purpose and travel. Tagdha and Tinchuley are connected with places of Bengal and Sikkim like Siliguri, New Jalpaiguri, Gorumara forest, Lataguri forest, Murti (dooars area), Hollong, Bagdogra, Darjeeling, Malbazar, Odlabari, Tinchuley, Gangtok, Pelling, Mirik, Ravangla, Gorubathan, Kalimpong, Jorethang, Pedong, Rangpoo, Kersiong etc. Car is the most popular mode of transport, especially in case of sightseeing purpose.

\section{ECONOMY}

Agriculture is one of the main economic sources of the inhabitants of Takdah and Tinchuley. There are several tea gardens in and around the areas among which Peshok, Namring, Gielle, Rangpoo, Lopchu, Rangli-Rangliot tea garden etc. Among these gardens, we visited the Gielle Tea Garden of Duncan Brothers near Takdah, which is 140 years old garden (Figure 6). The total area of the tea garden is around 417 hectares, and the plantation area is around 184 hectares. Mainly the Chinese varieties are cultivated in the garden, which is famous for flavor. The clonal varieties cultivated here are B157, AV2, RR17/144, TT78, P312 etc. Mainly organic farming is done for tea cultivation, very mild chemicals are used, as reported by the tea garden manager. Gravity fed irrigation system is followed in tea cultivation at Gielle Tea Garden. A gravity fed irrigation system is a cheap effective way to provide water for a smaller sized crop area. It would be especially cost effective if the climate of the area can provide enough precipitation to consistently keep a reservoir filled using rain water harvesting techniques. The basic system is very simple consisting of an elevated reservoir with a pipe coming out the bottom that feeds water into a basic drip irrigation system that is all controlled either by hand or with a very efficient battery powered timer that controls the rate at which the crop is watered. 
To categorize and classify some of the more unique teas, a system has been created know as the "Flush". The idea is this is indicative of when the tea was plucked within the harvest season. In Gielle tea garden, several phases of "flushes" can be observed. First Flush spans from mid-March to May, Second Flush from June to mid-August and Third Flush (Autumn Flush) from October to November [12]. The first two flushes can produce best quality tea in the garden.

However there are two minor flushes as well:

1. In-Between Flush for two weeks in-between the first and second flushes.

2. Rains/Monsoon Flush between the second and third flushes during the month of September.

There are 500 permanent workers in the tea garden and around 200 casual labour. Those include tea pluckers, tea makers, manager etc. We also visited the tea processing unit at Teesta Valley tea garden, where conventional sections are there, like: Withering section, Rolling section, Fermetting section, Dryer section and Sorting section. After processing, the tea is supplied in different parts of India and other countries.

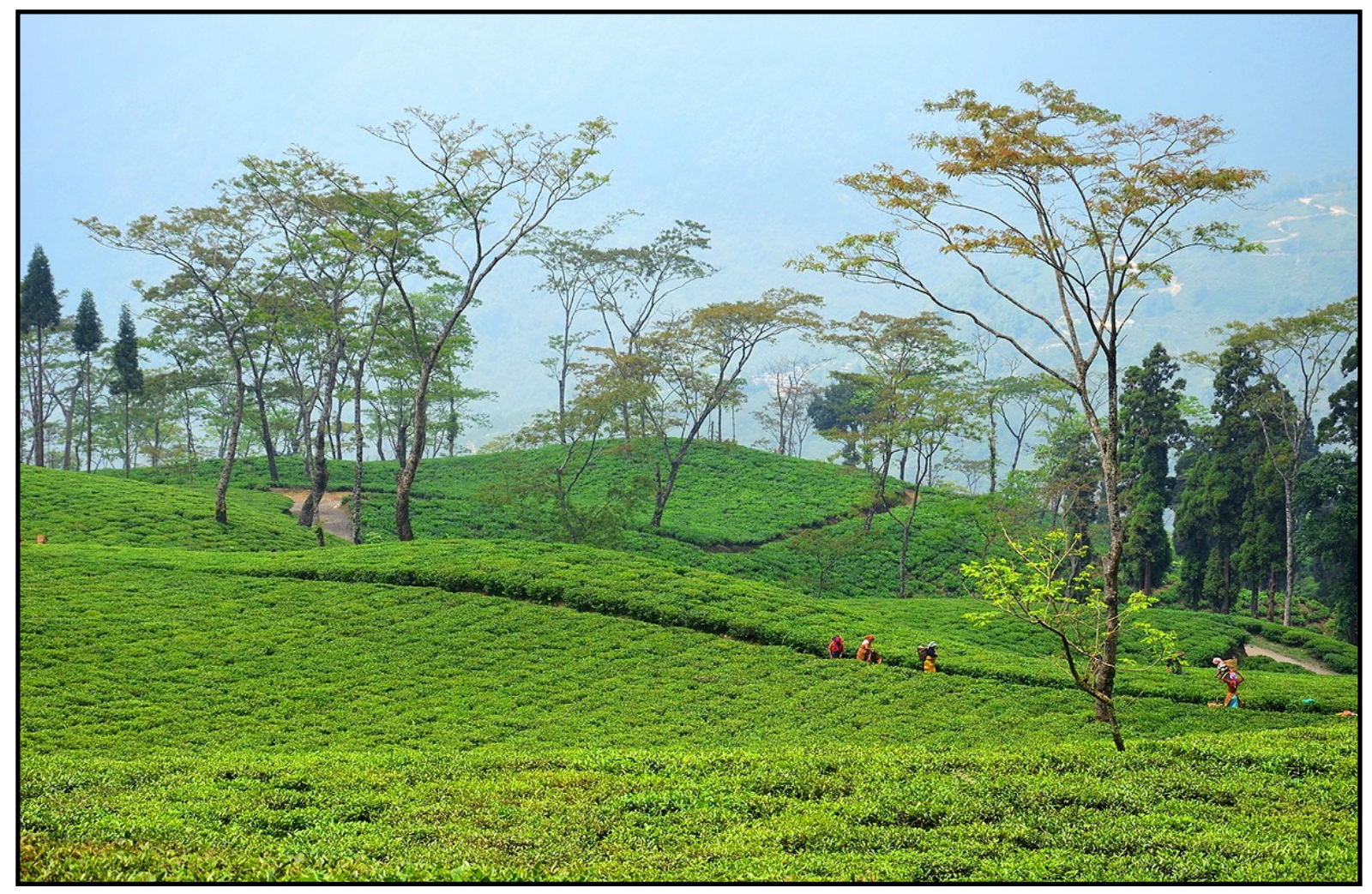

Figure 6. Gielle Tea Garden near Takdah.

Near Takdah, adjacent to the private orange orchard, there is a farm (Nirmal Farm), where several natural products are displayed and those products are supplied in Darjeeling, Siliguri and Kalimpong. The orange squashes sold there are made from the oranges cultivated in the orchard. Additionally, passion fruit squash, pickles, orange peel powder, vinegar etc. are also available in the shop (Figure 7). The orange gardens and private horticulture farms 
used to sell the cultured plants, seeds and plant products and distribute them in different parts of North Bengal. The main market of Takdah is the "Takdah Bazar" where the products are supplied from Siliguri and Poshupati Market (Nepal).

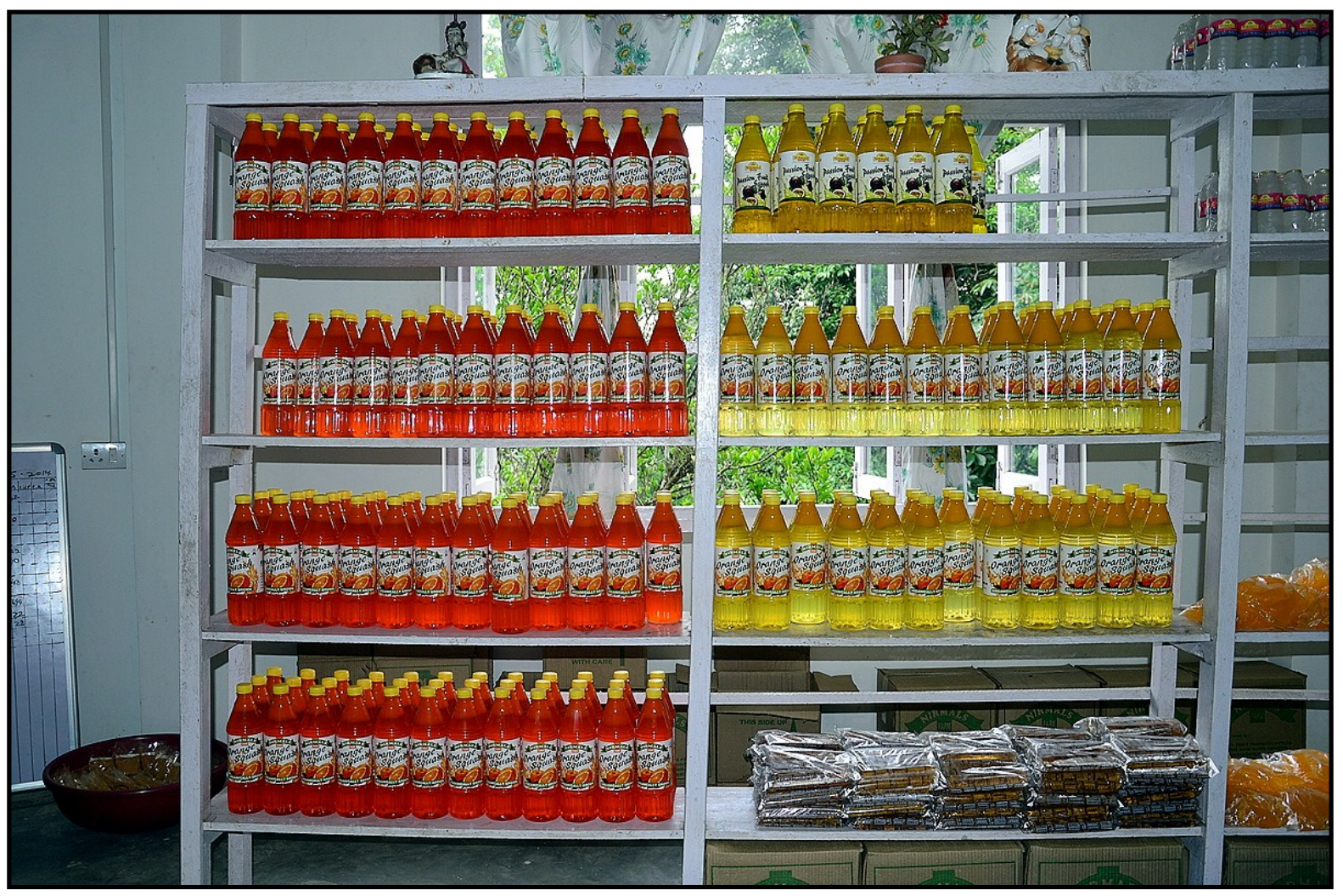

Figure 7. "Nirmal Farm", adjacent to the private orange orchard at Tinchuley.

\section{CONCLUSIONS}

Tinchuley and Takdah areas have become the prominent tourist spots of West Bengal for pleasure trips, biological and geographical excursions and medical research works. In spite of getting so much attention in the recent time, the areas are not adequately developed. There is an urgent need for implementing sustainable management systems in the areas for the betterment of the socio-environmental structures. Some of the implementable management systems are as follows:

1. The ecotourism spots of Tinchuley and Takdah are least advertised or given adequate publicity. Lack of systematic organization is another constraint of ecotourism in the study area. These issues should be addressed for the effective planning of sustainable ecotourism [13].

2. For reducing the water crisis in some specific zones of Tinchuley and Takdah area, micro scale rainwater harvesting structures should be installed in the houses. Filtering systems should be provided to the local inhabitants so that they can use the rainwater for drinking purpose after purifying it. 
2. Adequate health services should be provided to the local inhabitants of Tinchuley and Takdah. Health centers with sufficient number of doctors and nurses should be established in these areas. Separate operation theatre should be established in Takdah sub health centre.

3. Precaution should be taken for reducing the incidents of biopiracy, as these regions are very rich in medicinal plant resources. Government should take the initiatives for promoting and giving economic support to the private nurseries where several varieties of important plant species are preserved.

4. Large Cardamom (Amomum subulatum) production has been severely affected at Tinchuley due to water crisis (according to local reports). The issue should be investigated in detail and proper measures should be taken for the conservation of that local species.

5. In nurseries, there is a great problem of damping off disease caused by several fungi. Proper implementation and use of biopesticides and biofertilizers should be done in the agricultural and horticultural systems at Tinchuley and Takdah.

5. Local training centers should be established for teaching the local people about the importance of natural resources of Tinchuley and Takdah. The initiatives of the local people can effectively protect the natural assets of those areas.

6. Portfolio of tourism products should be developed by utilizing its unique ecological assets [13]. As these areas are the attraction for tourists, development of handicrafts made from the forest bioresources could be beneficial for the economic development of the local communities.

7. West Bengal is the cultural capital of India. It has constantly produced thoughts, ideas and events which have brought forth freshness and rejuvenation in the society both in India and the world. The specific components of Cultural Tourism which can be implemented in these areas include Fairs and Festivals Tourism, Arts and Crafts Tourism and Village Tourism.

8. Tourism carrying capacity is defined as the maximum number of people that may visit the tourist destination without causing destruction of the physical, economic and socio cultural environment and an unacceptable decrease in the quality of visitors' satisfaction. The carrying capacity assessment and sustainability of tourism in the circuits identified is an important component of the ecotourism study as it will form the basis for resource allocation and future development [13]. The carrying capacity assessment should be done separately for Tinchuley and Takdah, based on city population (resident), population density and tourist population and density (floating population).

9. There is lack of gross knowledge among villagers on the advantages of afforestation in the Hill areas. Specific training and awareness efforts from the Forest Department have to be undertaken to educate people on the drawbacks of deforestation and the long term effects it has on climate. In the silviculture unit, the plant varieties should be increased and more modern methods of conversation should be implemented associated with gene banks and extensive databases.

10. The effects of climate change are more severe in the Himalayas compared to the other regions [14]. The annual and seasonal temperature trends in the Kanchenjunga landscape indicate an increase at the rate $0.01-0.015^{\circ} \mathrm{C} /$ year, with higher altitudes experiencing greater warming [15]. Likewise, among the administrative units, Darjeeling was the most vulnerable compared to Sikkim, eastern Nepal and western Bhutan. Extensive studies on the 
effects of climate change on Tinchuley and Takdah should be done, as this zone represents one of the richest biodiversity zones of India. As tea plantation is one of the major economic sources of the regions, extensive studies should be done investing the effects of climate change on tea production and quality. The local tea workers informed that tea production has dropped in some tea gardens of Tinchuley and Takdah, but the scientific investigation is of foremost importance.

11. Like any other protected area in India, the forests of Takdah and Tinchuley suffer from illegal cattle grazing, firewood collection, encroachment on the fringes and poaching. However, due to inaccessibility and difficult terrain, the biotic pressures are still not very acute. More intense survey works and management practices should be done for mitigating the anthropogenic threats.

12. During the present study, a massive landslide was observed (Figure 8) near Teesta Bazar, at the meeting point of Teesta and Rangit rivers. Darjeeling valleys of Teesta and Rangit are under rapid habitat destruction due to several anthropogenic pressures and developmental activities like hydro-electrical projects, development of roads, establishment of tea gardens, mining and quarrying, landslides, forest fire etc. These factors jointly have increased the fragility of the Himalayan mountains, leading to an increase in the incidence of landslides in the region. Almost every year in monsoon season roads in this region get blocked due to landslides. Proper assessment of the geological frameworks should be done in these regions and the effects of increasing tourism and construction works should be evaluated in context of ecological and geological sensitivities of the region. Few patches of this area should be included in conservation network which would not only save the cycad but also other endemic and rare plants growing in their vicinity.

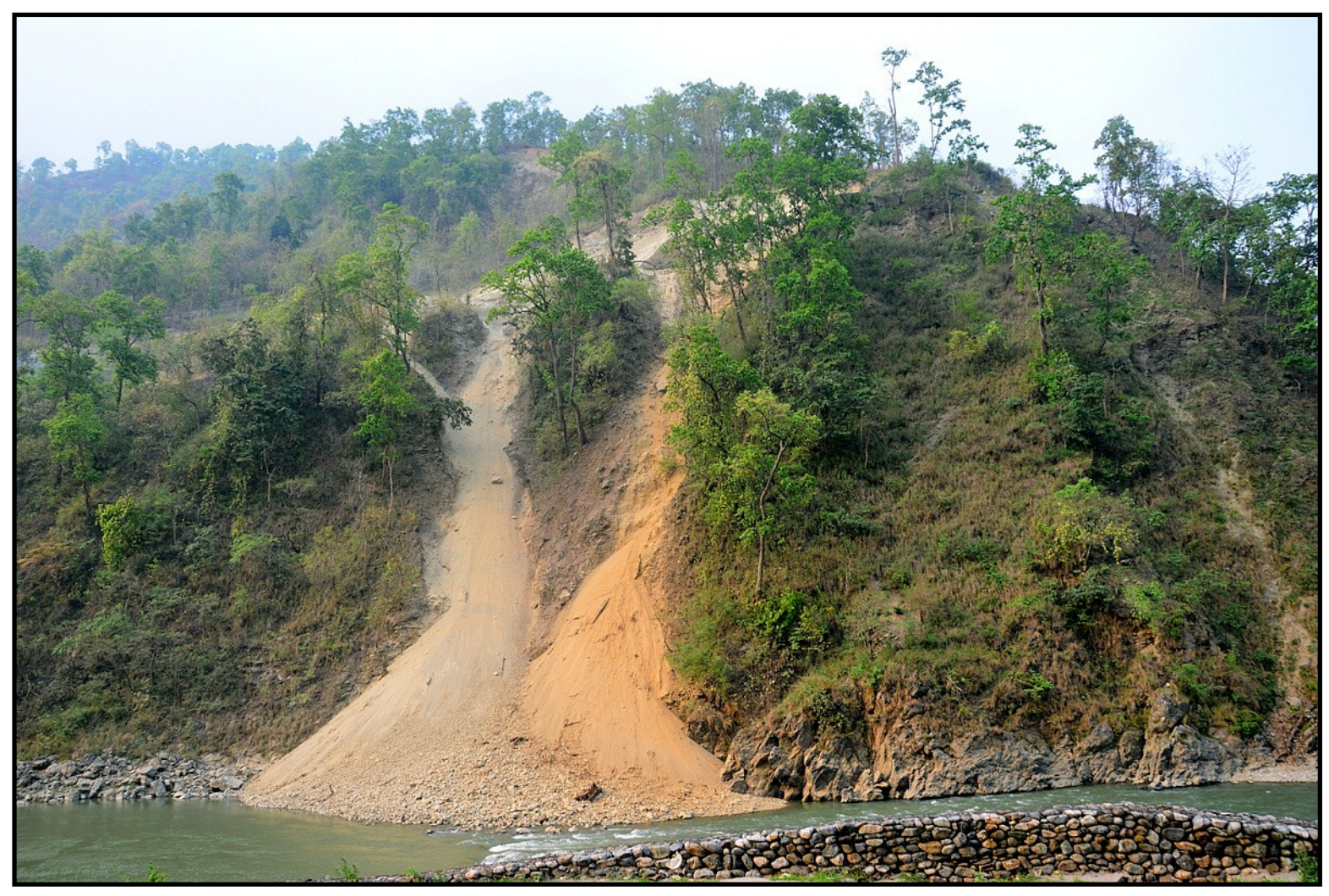

Figure 8. Landslide at Teesta Valley, near Tinchuley. 
13. Separate waste collection and disposal system should be operated by the government for safeguarding the sensitive ecosystems of the areas. Effective management design should be done for plastic wastes generated in these areas.

14. The vehicles used in the areas should be monitored regularly so that the vehicular pollution could be checked in the areas. Installation of the modern devices in the vehicles for pollution control should be done and routine checking system should be implemented.

15. To reduce the pressure on the forest and the drudgery to which women are subjected due to use of smoke producing "chullas", an alternative fuel policy should be evolved and implemented. Large scale installation of solar panels in these areas would be beneficial.

16. Proper land use pattern should be done, keeping the socio-economic and ecological parameters in view.

The mountain ranges and hill areas of India have a crucial role to play in determining the climate and physiography of the country and are prime determinants of development of plain areas. It is unquestionable that the hill areas of India, especially the Himalayas and the Nilgiris have major contributions in maintaining climatic and ecological balance in the country with their forests areas and watersheds. For a long time, these areas have not received their due emphasis on development issues.

The present work is the first ever socio-environmental study done at Tinchuley and Takdah so far. Extensive investigations at other hill areas of North Bengal should be done so that the places could be highlighted for conservation in future.

\section{References}

[1] Tinchuley. Accessed from: http://www.tinchuley.com/, Accessed on $23^{\text {rd }}$ June, 2014.

[2] Tinchuley. Accessed from: http://toursss.com/himalayan_villages_tab_7.php, Accessed on $23^{\text {rd }}$ June, 2014.

[3] Tinchuley. Accessed from: http://www.mytourideas.com/tinchuley.php, Accessed on $23^{\text {rd }}$ June, 2014.

[4] Takdah. Wikipedia. Accessed from: http://en.wikipedia.org/wiki/Takdah, Accessed on $23^{\text {rd }}$ June, 2014.

[5] Bhattacharya S., Shome A., Sarkar S., Purkait D., Ghosh U. C., International Letters of Social and Humanistic Sciences 17(2) (2014) 102-118.

[6] Directorate of Forests, Government of West Bengal. 1995. Tree improvement programme in silviculture (hills) division. Bulletin no. 4.

[7] Mulching. USDA (United States Department of Agriculture). Accessed from: http://www.nrcs.usda.gov/wps/portal/nrcs/detail/national/newsroom/?cid=nrcs143_0235 85, Accessed on $23^{\text {rd }}$ June, 2014.

[8] Cruz S., Jenkins C., What is Permaculture? Central rocky mountain permaculture institute. Accessed from: http://www.crmpi.org/CRMPI/What_is_Permaculture.html, Accessed on $23^{\text {rd }}$ June, 2014. 
[9] Citrus Tristiza Virus. Wikipedia. Accessed from: http://en.wikipedia.org/wiki/Citrus_tristeza_virus, Accessed on $23^{\text {rd }}$ June, 2014.

[10] How biodynamic agriculture works. Accessed from: http://en.wikipedia.org/wiki/Biodynamic_agriculture, Accessed on $22^{\text {nd }}$ May, 2014.

[11] Shneiderman, S., Turin, M. Seeking the tribe: Ethno-Politics in Darjeeling and Sikkim. Accessed from: http://www.digitalhimalaya.com/projectteam/turin/downloads/Seeking_Tribe.pdf, Accessed on $23^{\text {rd }}$ June, 2014.

[12] Darjeeling Tea. Wikipedia. Accessed from: http://en.wikipedia.org/wiki/Darjeeling_tea, Accessed on $23^{\text {rd }}$ June, 2014.

[13] Karmakar M., Tourismos 6(1) (2011) 251-270.

[14] IPCC. (2007). Climate Change 2007: Impacts, adaptation and vulnerability. Cambridge University Press, Cambridge, UK.

[15] Singh S.P., Bassignana-Khadka I., Karky B.S., Sharma E. (2011). Climate Change in the Hindu Kush-Himalayas: The State of Current Knowledge. International Centre for Integrated Mountain Development, Kathmandu, Nepal. 